\title{
Hubungan Peran Ketua Tim dengan Kinerja Perawat dalam Dokumentasi Asuhan Keperawatan di Rumah Sakit Jiwa Provinsi Jambi
}

\author{
Fithriyani $^{1}$,Miko EkaPutri ${ }^{2}$ \\ ${ }^{1,2}$ Prodi S1 Keperawatan STIKes Baiturrahim Jambi, Indonesia \\ Email: fithri.yani25@yahoo.co.id
}

Submitted : 04/12/2020

Accepted: 21/01/2021

Published: 06/03/2021

\begin{abstract}
The quality of service can be determined from the performance of the nurse in providing nursing care. The success of the team method in carrying out the nursing process is determined by the ability of the team leader to assign tasks to team members and direct work to the team. This study aims to knowing the relationship between the role of the team leader and the performance of nurses in documenting nursing care at the Jambi Provincial Psychiatric Hospital. A quantitative method with a cross-sectional survey using self-administered questionnaires The sampling technique was total sampling so that the sample size was 106 nurseswith analysis using the chi square test. The data were analyzed using statistical software. This study investigates the role of team leaders and nurses' performance in documenting nursing care. the role of the team leader in documenting nursing care was $54.1 \%$ good. the performance of nurses in documenting nursing care was $53.2 \%$ good. The statistical test results showed that the $p$ value $(0,000)<0.05$, which means that there is a significant relationship between the role of the team leader and the performance of nurses in nursing care documentation. This significant relationship explains that the role of the team leader will have a good influence on the documentation of nursing care carried out by the nurse in charge.
\end{abstract}

Keywords: documentation of nursing care, performance, role of team leader

\section{abstrak}

Kualitas pelayanan dapat ditentukan dari kinerja perawat dalam memberikan asuhan keperawatan.Keberhasilan metode timdalam melakukan proses keperawatan ditentukan oleh kemampuan pemimpin tim dalam memberikan tugas kepada anggota tim dan mengarahkan pekerjaan kepada tim.Penelitian ini bertujuan untuk mengetahui hubungan peran ketua tim dengan kinerja perawat dalam pendokumentasian asuhan keperawatan di Rumah Sakit Jiwa Provinsi Jambi. Metode penelitian kuantitatif dengan survei cross-sectional dengan menggunakan kuesioner. Teknik pengambilan sampel adalah total sampling sehingga jumlah sampel adalah 106 perawat dengan analisa menggunakan uji chi square. Hasil penelitian ini didapatkan peran ketua tim dalam mendokumentasikan asuhan keperawatan adalah $54,1 \%$ baik. Kinerja perawat dalam mendokumentasikan asuhan keperawatan 53,2\% baik. Hasil uji statistik menunjukkan bahwa nilai $p(0,000)<0,05$ yang berarti terdapat hubungan yang signifikan antara peran ketua tim dengan kinerja perawat dalam dokumentasi asuhan keperawatan. Dapat disumpulkan bahwa Hubungan yang signifikan ini menjelaskan bahwa peran ketua tim akan memiliki pengaruh yang baik terhadap pendokumentasian asuhan keperawatan yang dilakukan oleh perawat penanggung jawab.

Kata kunci: dokumentasi asuhan keperawatan, kinerja, peran ketua tim 


\section{PENDAHULUAN}

Kinerja perawat merupakan suatu tindakan yang dilakukan oleh seorang perawat dalam suatu organisasi sesuai dengan kewenangan dan tanggung jawabnya masing-masing, dimana kinerja yang baik dapat memberikan kepuasan kepada pengguna jasa dan juga meningkatkan mutu pelayanan keperawatan.1 Untuk mewujudkan mutu pelayanan keperawatan maka rumah sakit harus menerapkan proses sistem asuhan keperawatan di bangsal dengan menggunakan Model Praktik Keperawatan Profesional (MPKP).

Model praktik keperawatan profesional merupakan struktur penting dalam memberikan layanan keperawatan kepada klien.Praktik keperawatan profesional memungkinkan terwujudnya profesionalisme yang tinggi karena melalui praktik keperawatan profesional dapat diterapkan praktik berbasis pengetahuan. Ada beberapa metode penugasan MPKP yang dapat digunakan di bangsal, salah satunya adalah model praktik keperawatan profesional dengan metode tim 2.

Keberhasilan metode tim ditentukan oleh kemampuan pemimpin tim dalam memberikan tugas kepada anggota tim dan mengarahkan pekerjaan tim. Perawat yang bertindak sebagai ketua tim bertanggung jawab untuk mengetahui kondisi dan kebutuhan semua pasien dalam tim dan merencanakan perawatan pasien. Tugas ketua timmeliputi: menilai anggota tim, memberikan arahan perawatan untuk pasien, melakukan pendidikan kesehatan, mengkoordinasikan kegiatan pasien. Kinerja perawat dalam metode tim melaksanakan asuhan keperawatan yang dapat diukur dari pendokumentasian asuhan keperawatan yang dilakukan. Dokumentasi yang buruk menggambarkan kinerja perawat dalam pelaksanaan asuhan keperawatan.
Faktor-faktor yang mempengaruhi kinerja. Menurut Gibson, Ivancevich dan Donally dalam Ilyas (2002) dapat dikelompokan dalam variabel individu, psikologis dan keorganisasian. Faktor individu meliputi kemampuan dan keterampilan, latar belakang dan demografi.Faktor psikologis meliputi persepsi, sikap dan motivasi.Faktor organisasi meliputi sumber daya, kepemimpinan, imbalan, supervisi.

Rumah Sakit Jiwa Provinsi Jambi telah menerapkan metode penugasan MPKP dalam bentuk metode tim sejak tahun 2014 di beberapa ruang rawat inap. Terdapat 14 ruang rawat inap dengan total 106 perawat, dengan 13 jenjang pendidikan yang terdiri dari sarjana / perawat, 93 diploma keperawatan. Berdasarkan pengalaman membimbing mahasiswa di RSJ Provinsi Jambi, pelaksanaan pendokumentasian asuhan keperawatan belum terlaksana dengan baik. Hal tersebut dapat terjadi karena beberapa faktor antara lain pemahaman tentang pengisian dokumentasi sesuai standar, peran ketua tim dalam mengarahkan dan mengawasi pelaksanaan asuhan keperawatan dengan tepat.

Penelitian ini bertujuan untuk mengetahui hubungan peran ketua tim dengan kinerja perawat dalam pendokumentasian asuhan keperawatan di Rumah Sakit Jiwa Provinsi Jambi dengan rumusan masalah bagaimanahubungan peran ketua tim dengan kinerja perawat dalam pendokumentasian asuhan keperawatan.

\section{METODE PENELITIAN}

Jenis penelitian kuantitatif dengan pendekatan cross-sectional dengan menggunakan kuesioner. Teknik pengambilan sampel adalah total sampling sehingga jumlah sampel adalah 106 perawat. Analisis data univariat dan bivariatat dengan uji chie square. Data dianalisis dengan menggunakan computer 


\section{HASIL DAN PEMBAHASAN}

\section{A. Karakteristik}

Tabel 1 Karakteristik demografi responden $(n=109)$

\begin{tabular}{lcc}
\hline Karakteristik & Frekuensi & Persentase (\%) \\
\hline Lama kerja & 30 & 27,5 \\
$<5$ tahun & 79 & 72,5 \\
$\geq 5$ tahun & & \\
\hline Tingkat pendidikan & 4 & 3.7 \\
SPK & 72 & 66.1 \\
D3 keperawatan & 17 & 15.6 \\
Sarjana keperawatan & 16 & 14.7 \\
Ners & & \\
\hline
\end{tabular}

Karakteristik demografi dari 109 responden menunjukkan bahwa sebagain besar responden adalah rata-rata usia perawat 34,28 tahun dengan usia termuda 24 tahun dan tertua 57 tahun. Sebagian pendidikan responden.

\section{B. Analisa Univariat}

Analisa univariat dari penelitian ini tentang peran ketua tim dan kinerja perawat

Tabel 2 Peran ketua tim dan kinerja perawat dalam mendokumentasikan asuhan keperawatan $(\mathbf{n}=109)$

\begin{tabular}{lcc}
\hline Variable & Frekuensi & Percentase (\%) \\
\hline Peran ketua tim & 50 & \\
Kurang baik & 59 & 45.9 \\
Baik & & 54.1 \\
\hline Kinerja perawat & 51 & \\
Kurang baik & 58 & 46.8 \\
Baik & 53.2 \\
\hline
\end{tabular}

Dari table diatas didapatkan Bahwa lebih dari separuh peran ketua tim dalam pendokumentasian asuhan keperawatan adalah $54,1 \%$ baik. Sejalan dengan penelitian Widya $\mathrm{N}$ dkk tahun 2016 tentang hubungan peran ketua tim dengan kinerja perawat pelaksana dalam mendokumentasikan asuhan keperawatan di IRINA F. Lebih dari separuh kinerja perawat dalam mendokumentasikan besar perawat dengan masa kerja $\geq 5$ tahun adalah $72,5 \%$ dan perawat memiliki pendidikanD3 keperawatan $66,1 \%$. Tabel 1 menjelaskan, tahun pengalaman dan tingkat 
pada pasien selama dirawat di rumah sakit hingga sembuh

\section{Analisa Bivariat}

Berikut Tabel 3 tentang Hubungan antara peran ketua tim dan kinerja perawat dalam pendokumentasian asuhan keperawatan

\begin{tabular}{|c|c|c|c|c|c|c|c|}
\hline \multirow{3}{*}{ Peran ketua tim } & \multicolumn{6}{|c|}{ Kinerja perawat } & \multirow{3}{*}{$\begin{array}{c}P- \\
\text { value }\end{array}$} \\
\hline & \multicolumn{2}{|c|}{ Kurang baik } & \multicolumn{2}{|c|}{ Baik } & \multicolumn{2}{|c|}{ Total } & \\
\hline & $F$ & $\%$ & $\mathrm{~F}$ & $\%$ & $\mathrm{f}$ & $\%$ & \\
\hline Kurang baik & 37 & 33,9 & 13 & 11,9 & 50 & 45,9 & 0000 \\
\hline Baik & 14 & 12.8 & 45 & 41.3 & 59 & 54.1 & \\
\hline Total & 51 & 46.8 & 58 & 53,2 & 109 & 100,0 & \\
\hline
\end{tabular}

Dari 50 responden yang perannya sebagai ketua tim kurang baik, kinerja dokumentasi asuhan keperawatan kurang baik $33,9 \%$ dan baik $11,9 \%$. Sedangkan dari 59 responden yang peran ketua tim baik dengan kinerja perawat dalam pendokumentasian asuhan keperawatan, $12,8 \%$ termasuk buruk dan $41,3 \%$ baik. Hal ini menunjukkan bahwa peran ketua tim yang baik semakin besar dalam meningkatkan kinerja dokumentasi asuhan keperawatan. Hasil uji statistik menunjukkan bahwa nilai p $(0,000)<0,05$ yang berarti terdapat hubungan yang signifikan antara peran ketua tim dengan kinerja perawat dalam pendokumentasian asuhan keperawatan di RSJ Provinsi Jambi.

Lebih dari separuh peran ketua tim dalam pendokumentasian asuhan keperawatan adalah $54,1 \%$ baik. Perawat yang bertindak sebagai ketua tim bertanggung jawab untuk mengetahui kondisi dan kebutuhan semua pasien dalam tim dan merencanakan perawatan pasien. Hal tersebut tidak terlepas dari motivasi ketua tim kepada perawat yang melaksanakan asuhan keperawatan khususnya dokumentasi.Bahwa lebih dari separuh kinerja perawat dalam mendokumentasikan asuhan keperawatan adalah 53,2\% baik. Penelitian ini sejalan dengan penelitian Suryandana (2010) di RS Puri Indah, Jakarta yang menunjukkan bahwa terdapat hubungan antara peran ketua tim dengan dokumentasi asuhan keperawatan dan hasil penelitian Widodo, Widya N, dkk. (2016) yang dilakukan di Irina F Prof.Dr.RD Kandou Manado, ditemukan adanya hubungan antara peran team leader dengan kinerja perawat dalam mendokumentasikan asuhan keperawatan di Irina F Prof.Dr.RD Kandou Manado.

Hubungan yang signifikan ini menjelaskan bahwa peran ketua tim akan memberikan pengaruh yang baik terhadap pendokumentasian asuhan keperawatan yang dilakukan oleh perawat penanggung jawab. Pendokumentasian asuhan keperawatan membutuhkan sistem manajerial yang tepat dalam mengarahkan semua sumber daya keperawatan yang berkualitas akan mencapai tujuan pelayanan keperawatan.

\section{SIMPULAN}

Peran ketua tim akan memberikan pengaruh yang baik terhadap pendokumentasian asuhan keperawatan yang dilakukan oleh perawat penanggung jawab. Pendokumentasian asuhan keperawatan memerlukan sistem manajerial yang tepat untuk mengarahkan semua sumber daya keperawatan yang berkualitas untuk mencapai tujuan pelayanan keperawatan.

\section{UCAPAN TERIMA KASIH}

Penulis mengucapkan terima kasih yang sebesar-besarnya kepada Sekolah 
Tinggi Ilmu Kesehatan Baiturahim Jambi yang telah mendanai penelitian ini hingga selesai. Kepada tim dosen Prodi S1 Keperawatan yang senantiasa mendukung kegiatan penelitian ini.

\section{DAFTAR PUSTAKA}

Murti B. Teori Promosi Dan Perilaku Kesehatan. 1st ed. Surakarta: Bintang Fajar Offset; 2018

Kementerian Kesehatan Republik Indonesia.Pedoman uraian tugas tenaga keperawatan di rumah sakit. Jakarta: Kementerian Kesehatan ;2012

Sitorus, Ratna. Manajemen Keperawatan Manajemen Keperawatan Ruang Bangsal, Jakarta: Sagung Seto;2011.

Cheevakasemsook et. Al. (Perbandingan Rekaman Efektivitas- kebutuhan Fokus dan Model Rekam Keperawatan Berorientasi Masalah (Tesis Med (Administrasi Keperawatan)), Bangkok; Universitas Chulalongkorn;2006

Marquis, B.L. \& Hustin, C.J. Peran Kepemimpinan dan Fungsi Manajemen Keperawatan: Teori dan Aplikasi. Philadelphia;2000

Nursalam. Manajemen Keperawatan: Aplikasi dalam praktik keperawatan profesional. Edisi 5. Jakarta. Salemba Medika; 2015
Suryandana, Hubungan Peran Ketua Tim dengan Kinerja Perawat Pelaksana Dalam Pendokumentasian Asuhan Keperawatan di Ruang Operasi RSUD Puri Indah Jakarta. Jurnal Program Studi Keperawatan Fakultas Ilmu Kesehatan Universitas Esa Unggul. Diunduh 9 November 2015.;2010

Pujiyanto, Eko Nur, dan Rosiana Nur Imallah. Hubungan peran ketua tim dengan pendokumentasian asesmen keperawatan pada perawat di ruang rawat inap dewasa RS PKU Muhammadiyah Bantul. Diss. Universitas Aisyiyah Yogyakarta, ;2018.

Widodo, W. N., Wungow, H., \& Hamel, R. S. Hubungan Peran Ketua Tim dengan Kinerja Perawat Pelaksana dalam Pendokumentasian Asuhan Keperawatan di Irina F Rsup Prof. Dr. RD Kandou Manado. JURNAL KEPERAWATAN, 4 (2).;2016

Swanburg, R. C. Pengantar kepemimpinan dan manajemen keperawatan, untuk perawat klinis. Penerbit Buku Medis EGC. Jakarta; 2000

Heriansyah, H. Tanggung jawab penerapan metode tim dengan kinerja perawat dalam mendokumentasikan asuhan keperawatan di Irna Rsud Ratu Zalecha Martapura.Jurnal.Nersp edia, $1 \quad$ (2), 147-155; 2018 